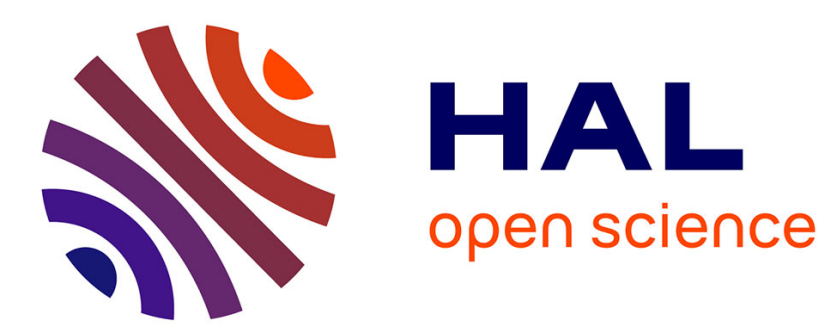

\title{
Size and dispersion of urticating setae in three species of processionary moths
}

\author{
Edoardo Petrucco Toffolo, Daniel Zovi, Chiara Périn, Paolo Paolucci, Alain \\ Roques, Andrea Battisti, Helmuth Horvath
}

\section{- To cite this version:}

Edoardo Petrucco Toffolo, Daniel Zovi, Chiara Périn, Paolo Paolucci, Alain Roques, et al.. Size and dispersion of urticating setae in three species of processionary moths. Integrative Zoology, 2014, 9 (3), pp.320-327. 10.1111/1749-4877.12031 . hal-02633992

\section{HAL Id: hal-02633992 \\ https://hal.inrae.fr/hal-02633992}

Submitted on 27 May 2020

HAL is a multi-disciplinary open access archive for the deposit and dissemination of scientific research documents, whether they are published or not. The documents may come from teaching and research institutions in France or abroad, or from public or private research centers.
L'archive ouverte pluridisciplinaire HAL, est destinée au dépôt et à la diffusion de documents scientifiques de niveau recherche, publiés ou non, émanant des établissements d'enseignement et de recherche français ou étrangers, des laboratoires publics ou privés. 


\title{
Size and dispersion of urticating setae in three species of processionary moths
}

\author{
Edoardo Petrucco Toffolo ${ }^{1}$, Daniel Zovi ${ }^{1}$, Chiara Perin ${ }^{1}$, Paolo Paolucci ${ }^{1}$, Alain \\ Roques $^{2}$, Andrea Battisti ${ }^{1}$, Helmuth Horvath ${ }^{3}$
}

1. University of Padova, DAFNAE-Entomology, Agripolis, 35020 Legnaro PD, Italy, andrea.battisti@unipd.it

2. INRA, UR0633, Zoologie Forestière, 2163 Av. Pomme de Pin, Ardon 45075

Orléans, France, alain.roques@orleans.inra.fr

3. Institut für Experimentalphysik, Universität Wien, 1090 Vienna, Austria, horvath5@login.univie.ac.at

Corresponding author

Andrea Battisti

University of Padova, DAFNAE-Entomology, Agripolis, 35020 Legnaro PD, Italy,

Tel. +390498272804

Fax +390498272810

andrea.battisti@unipd.it

This article has been accepted for publication and undergone full peer review but has not been through the copyediting, typesetting, pagination and proofreading process, which may lead to differences between this version and the Version of Record. Please cite this article as doi: 10.1111/1749-4877.12031 


\title{
Acknowledgements
}

We warmly acknowledge all the people that have provided help for this work and especially F. Goussard and J. Garcia. We are also indebted to S. Larsson, D. Lees, M. Simonato, M. Stastny and C. Villari for reviewing an earlier version of the manuscript. This work was funded by French National Research Agency in the framework of project ANR n07BDIV 013 'URTICLIM' and by the University of Padova grant 2010 C91J10000320001.

\begin{abstract}
Larvae of the processionary moths of the Palaearctic region bear urticating setae that are released against vertebrate predators, especially insectivorous birds. A few species are pests of forest and urban trees and consequently may threaten human and animal health during outbreaks, causing dermatitis, conjunctivitis, and respiratory distress. Although some studies provide detailed information about the setae, particularly those of the pine processionary moth Thaumetopoea pityocampa (Denis \& Schiffermüller), there is little knowledge about morphological traits of the setae and their release by the larvae. We here identify the major traits of the setae of three species of processionary moth, namely Thaumetopoea pityocampa, T. pinivora (Treitschke), and T. processionea (Linnaeus), potentially helpful in understanding of setae dynamics in the environment: (i) diameter and length of setae; (ii) analysis of dynamical properties of the setae in the airborne state. Setae are highly variable in size, with bimodal distribution in T. pityocampa and T. pinivora; in these two species short and long setae are interspersed within the integument fields where they occur. The difference in the seta size has important consequence in dispersion, as smaller setae can spread 5 times further than their bigger counterparts. This information is relevant to a full understand of the defensive importance of larval setae against natural enemies of the processionary moths, as well as to understanding the importance of the processionary setae as air pollutants, both close to the infested trees and at longer distance.
\end{abstract}

Key words: bio-aerosol, Lepidoptera, pollution, seta dispersion, seta size,

\section{Thaumetopoea}




\section{Introduction}

Some Lepidoptera, as larvae or adults, carry urticating setae that are generally considered to be a defense against vertebrate predators (Gilmer 1925; Pesce \& Delgado 1971; Kawamoto \& Kumada 1984), but which also pose a serious threat to human health (Specht et al. 2008; Hossler 2009; Mullen 2009; Battisti et al. 2011). In contrast to spines that are firmly attached to the integument and require a contact with the larva to cause the reaction (e.g. the larvae of Saturniidae, Megalopygidae, and Limacodidae) (Specht et al. 2008), setae are readily dehiscent from the integument and can disperse in the environment, often far away from the infested trees (Werno \& Lamy 1990, Maier et al. 2003).

The urticating setae of the larvae of processionary moths, namely the pine processionary moth Thaumetopoea pityocampa, the northern pine processionary moth T. pinivora, and the oak processionary moth $T$. processionea (Lepidoptera, Notodontidae), have been well known since ancient times for their 'burning' effect (Matthioli 1568). Indeed, there are numerous reported cases of resulting dermatitis, conjunctivitis, and respiratory distress in humans (Vega et al. 1999; Maier et al. 2003; Gottschling \& Meyer 2006, Vega et al. 2011). In addition, an allergic response has been recently shown in a number of cases (Vega et al. 1999; Moneo et al. 2003; Fuentes Aparicio et al. 2006; Santos-Magadàn et al. 2009; Rodriguez-Mahillo et al. in press). Setal production and morphology was first studied in the pioneering work of Fabre (1900), continued by Démolin (1963), Lamy et al. (1982), and Novak et al. (1987). The urticating setae are produced from the $3^{\text {rd }}$ larval instar or $4^{\text {rd }}$ larval instar, depending on the species, on integument areas of the abdominal tergites that are called 'mirrors' owing to their property to reflect light. These mirrors increase in number with larval molts until the last larval instar, in which they occur on eight abdominal segments. At this stage there are about 1,000,000 setae/larva in T. pityocampa, with a density of $60,000 \mathrm{setae} / \mathrm{mm}^{2}$; setae are a few hundred micrometer long, with a sharp proximal end and pointed barbs directed distally (Lamy 1990). These setae are renewed at each molt and many are left with the old skin, so that they occur in a high number in tents used by larval colonies on trees as well as at pupation sites.

The release of setae by the larvae was explored by Démolin (1963), who showed that the larvae may actively open the integument mirrors when disturbed. Werno and 
Lamy (1990) found setae in pollen traps, with the abundance of setae progressively decreased moving away from the infested forest. Fenk et al. (2007) developed a setal dispersion model for the oak processionary moth, $T$. processionea, based on their physical properties in relation to prevailing wind. The authors showed that the maximum concentration of setae spread at a distance of 200 to 500 meters, depending on temperature and wind speed; even at a distance of $2 \mathrm{~km}$ considerable numbers of setae could occur. This is important because most reactions in humans are associated with airborne setae (Maier et al. 2003; Fuentes Aparicio et al. 2006; Gottschling \& Meyer 2006; Vega et al. 2011). An aggravating factor is the long persistence of the setae in the environment even after exposure to rather extreme conditions: Hase (1939) demonstrated that dried insects retain their irritating power after 12 years of preservation and after treatment with temperature as high as $110^{\circ} \mathrm{C}$.

In this paper we address a few traits of the setae of three Thaumetopoea species that can be useful to clarify their importance as environmental hazards. Specifically we investigate: i) the variation in size of setae; ii) the dynamical properties of setae in the airborne state according to their size. We hypothesize that the different size of setae could be functional to improve the protection of colonies from predation, and in turn may have an impact on non-target vertebrates exposed to them, such as humans and domestic mammalians.

\section{Materials and methods}

\section{Insects}

To obtain samples of urticating setae of the three Thaumetopoea species, we collected larvae in the last instar from rearing in Padova University campus or from colonies in natural conditions. Samples were collected in 2008 from Tregnago (Italy) (45³0’ N, $11^{\circ} 11^{\prime} \mathrm{E}, \mathrm{m} 477$ ) for $T$. pityocampa, from the island of Gotland (Sweden) (56 $56^{\circ} \mathrm{N}$, $\left.18^{\circ} 16^{\prime} \mathrm{E}, \mathrm{m} 7\right)$ in 2009 for T. pinivora, and from Caprino Veronese (Italy) (45 $35^{\prime} \mathrm{N}$, $\left.10^{\circ} 47^{\prime} \mathrm{E}, \mathrm{m} 245\right)$ in 2009 for $T$. processionea. 


\section{Dynamical properties}

In order to explore the length and diameter of setae, we randomly selected 10 individuals, each one from a different colony, that were directly frozen after the collection. Setae were randomly extracted with forceps from mirrors under stereomicroscope and were measured using a scanning electron microscope (SEM Hitachi TM-1000) ( $\mathrm{n}=108$ for T. pityocampa, $\mathrm{n}=120$ for $T$. pinivora, and $\mathrm{n}=175$ for $T$. processionea).

In order to evaluate the behavior of setae in the environment and their dispersion capacity, we analyzed their main aerodynamic features. A descriptive characterization of setae is done with the aerodynamic diameter $\mathrm{d}_{\mathrm{ae}}$, which is the hypothetic diameter that a water droplet would have in order to settle with the same velocity as the particle under consideration. The measures of aerodynamic diameter allow calculating the settling velocity (resulting from the force of gravity and the friction by the air molecules surrounding):

$$
v_{s}=\rho_{\text {water }} \cdot d_{\text {aes }}^{2} \cdot q /(18 \eta)
$$

where $\mathrm{g}$ is the acceleration of gravity, $\rho_{\text {water }}$ is water density and $\eta$ is the viscosity of the air.

We obtained the aerodynamic diameter using equations provided by Cox (1970) and the diameter and length of setae measure by SEM microscopy. The following equations were used in the calculations, with the first giving the aerodynamic diameter for movement parallel to the setae major axis and the second for movement perpendicular to the axis:

$$
\begin{aligned}
& d_{, a \varepsilon \|}=d_{f} \sqrt{\left.\frac{9 \rho_{f}}{4 \rho_{f}} \mid \ln (2 \beta)-0.807\right) \mid} \\
& d_{\text {sae }}=d_{f} \sqrt{\left.\frac{9 \rho_{f}}{8 \rho_{f}}[\ln (2 \beta)+0.193)\right]}
\end{aligned}
$$

where $d_{\mathrm{f}}$ is the seta diameter, $\rho_{\mathrm{f}}$ the seta density (with the value of $1,100 \mathrm{~kg} / \mathrm{m}^{3}$ ), $\rho_{0}$ unit density and $\beta$ the aspect ratio.

Knowing these parameters, we calculated the potential distance of spreading setae, reaching the ground at the distance of $L=h c / v_{s}$ (where $h$ is the height of setae release, $\mathrm{c}$ the wind velocity, $\mathrm{v}_{\mathrm{s}}$ the settling velocity). Although this expression is only 
valid for laminar flow, it is a good indicator for spreading also in turbulent flow conditions.

\section{Length of released setae}

In order to evaluate the length of the setae released by larvae after a mechanical disturbance, we collected one larva from each colony, which were individually transferred to a cylindrical vial $(17 \times 45 \mathrm{~mm})$ with a flat bottom. The opening was sealed with an adhesive transparent PVC tape (Comet ${ }^{\circledR}$, Tesa AG - Hamburg, D). The vial was then vortexed, using a Vortex ${ }^{\circledR} \mathrm{RX} 3$ mixer at 2,400 rpm for 10 seconds, to simulate a mechanical disturbance, such as a typical attack by a vertebrate predator (Barbaro \& Battisti 2011). After the treatment, the adhesive tape seal (diameter $14 \mathrm{~mm}$ ) was removed with a scalpel and transferred to a microscope slide. Digital photographs from the central part of the disc (photograph area $1.2 \times 1.8 \mathrm{~mm}$ ) were taken at the microscope and the pictures were analyzed for measuring the length of the setae present. The sampled setae were collected from last instar larvae (T. pityocampa $\mathrm{n}=5, T$. pinivora $\mathrm{n}=9$, . processionea $\mathrm{n}=8$ ).

\section{Scanning electron microscope analysis}

Last instar larvae of the three species were used to observe the distribution of the setal length classes in the urticating apparatus. Larvae from the freezer were kept on ice under a stereomicroscope and dissected transversally to the fields carrying the setae. The specimens were observed by scanning electron microscopy (SEM Hitachi TM1000) equipped with a cool stage unit (MK3 model, Deben UK), which maintained the specimens at temperature below the zero to avoid water evaporation.

\section{Statistics}

The best fit of distribution of aerodynamic diameter was obtained through a nonlinear regression, assuming a sum of two normal distributions in case of bimodality. The relationships between setal length and diameter were analyzed by regression analysis. To test for normality in the distribution of the length of released setae, the KolmogorovSmirnov test was used. 


\section{Results}

\section{Dynamical properties}

In $T$. pityocampa, the distribution of aerodynamic diameter showed a bimodal distribution (Fig. 1). The best fit to the data is by the sum of two Gauss curves, the optimum function is:

$$
y=a_{1} \cdot \exp \left(-0.5 \cdot\left(\left(x-x_{1}\right) / b_{1}\right)^{2}\right)+a_{2} \cdot \exp \left(-0.5 \cdot\left(\left(x-x_{2}\right) / b_{2}\right)^{2}\right)
$$

where $x_{1}$ and $x_{2}$, respectively 7 and $13.6 \mu \mathrm{m}$, are the mean diameter of two different populations of setae, $b_{1}\left(1 \mu \mathrm{m}^{2}\right)$ and $b_{2}\left(1.8 \mu \mathrm{m}^{2}\right)$ the square of the standard deviation, and the two parameters $\mathrm{a}_{1}(8.8)$ and $\mathrm{a}_{2}$ (12) are the number of setae of the two modes in this sample. The average settling velocity of long setae $(6.1 \mathrm{~mm} / \mathrm{s})$ was 5 times higher than that of short setae $(1.6 \mathrm{~mm} / \mathrm{s})$. The horizontal distance traveled for a seta released at $20 \mathrm{~m}$ of height in a day with a wind velocity of $2 \mathrm{~m} / \mathrm{s}$ is $6.5 \mathrm{~km}$ for the short setae and $2.4 \mathrm{~km}$ for the long setae.

The distribution of the aerodynamic diameter of $T$. pinivora is bimodal and the best fit to the data is by the sum of two Gauss curves, with the equation:

$$
y=a_{1} \cdot \exp \left(-0.5 \cdot\left(\left(x-x_{1}\right) / b_{1}\right)^{2}\right)+a_{2} \cdot \exp \left(-0.5 \cdot\left(\left(x-x_{2}\right) / b_{2}\right)^{2}\right)
$$

where $\mathrm{x}_{1}$ and $\mathrm{x}_{2}$, respectively 7.6 and $12.9 \mu \mathrm{m}$, are the mean diameter of two different populations of setae, $b_{1}\left(1.7 \mu \mathrm{m}^{2}\right)$ and $b_{2}\left(1 \mu \mathrm{m}^{2}\right)$ the square of the standard deviation of $\mathrm{x}_{1}$ and $\mathrm{x}_{2}$, and the two parameters $\mathrm{a}_{1}(9.6)$ and $\mathrm{a}_{2}(26.2)$ are the number of setae of the two modes in this sample.

The settling velocities are 1.9 and $5.4 \mathrm{~mm} / \mathrm{s}$, respectively, and the corresponding dispersion distances are 21 and $7.4 \mathrm{~km}$.

In $T$. processionea, the distribution of aerodynamic diameter is unimodal and peaks at $12.3 \mu \mathrm{m}$ (variance $1.59 \mu \mathrm{m}^{2}$ ). The best fit is:

$$
y=a \cdot \exp \left(-0.5 \cdot\left(\left(x-x_{0}\right) / b\right)^{2}\right)
$$

where $x_{0}(12.3 \mu \mathrm{m})$ is the mean diameter of setae, $b\left(1.6 \mu \mathrm{m}^{2}\right)$ the square of its standard deviation, and the parameter a (39.4) is the number of setae of the mode.

The settling velocity is $5 \mathrm{~mm} / \mathrm{s}$, resulting in a dispersion of $8 \mathrm{~km}$ for a release at $20 \mathrm{~m}$ of height and a wind velocity of $2 \mathrm{~m} / \mathrm{s}$, under laminar flow conditions.

It must be mentioned that the velocities and distances given above are for the 
mean aerodynamic diameter. Since the velocity is inversely proportional to the square aerodynamic diameter, the smaller setae will spread much further. Setal diameter and length were highly correlated in the three species according to a logarithmic function (Fig. 2), with a higher slope for short setae. The $\mathrm{R}^{2}$ values were statistically significant in all the cases, and were higher for T. pityocampa (0.92) and for T. pinivora (0.90) than for $T$. processionea $(0.62)$.

\section{Length of released setae}

The analysis of setae released by the larvae showed a distribution different from the normal one (Kolmogorov-Smirnov test: T. pityocampa, $\mathrm{D}=0.12, \mathrm{p}<0.01$; . pinivora, $\mathrm{D}$ $=0.12, \mathrm{p}<0.01 ;$. processionea $, \mathrm{D}=0.07, \mathrm{p}<0.01)$ but with differences shapes among species (Fig. 3). The shape was bimodal in T. pityocampa and T. pinivora, with a first peak in the class of 50-100 $\mu \mathrm{m}$ and a second peak in the class of 200-250 $\mu \mathrm{m}$. In $T$. pityocampa, the first peak (22.6\% of setae) was higher than the second peak whereas in T. pinivora the peaks were similar (both about 25\%). There was further difference for the range of variation of seta length, as this was wider in T. pityocampa $(46-681 \mu \mathrm{m})$ than in $T$. pinivora $(47-492 \mu \mathrm{m})$. A completely different situation occurred in $T$. processionea, which showed a single peak in the class of 200-250 $\mu \mathrm{m}$, and a range (56$351 \mu \mathrm{m})$ shorter than the one of the other two species. Moreover, the distribution was skewed to the left in $T$. pityocampa (skewness index $=0.99$ ) and in $T$. pinivora (skewness index $=0.32$ ), whereas in the $T$. processionea the distribution was symmetric ( skewness index $=-0.01$ ).

\section{Distribution of setae in the urticating apparatus}

The picture of the setae in the mirrors showed differences among the three species. In $T$. pityocampa and T. pinivora we observed two well defined levels of setae length, that cohabit on the whole surface of the mirror, whereas this was not the case for $T$. processionea (Fig. 4). 


\section{Discussion}

Although the setal system of processionary moth has been the subject of a large number of studies, for both morphological and functional traits (Fabre 1900; Scheidter 1934;

Démolin 1963; Lamy et al. 1982), the distribution of setal length in an individual remained unknown. Here, we present the first detailed description of the size of setae in three processionary moth species. We found a markedly different pattern of setae length from that expected by previously published data, and we showed that the differences in setal size have implications on the dynamical properties. In particular, short setae like the ones that occur in two of the three species are able to spread farther away than long setae.

The results showed a wide variation in setal length. In the case of T. pityocampa the longest $(680 \mu \mathrm{m})$ were about 14 times longer than the shortest $(50 \mu \mathrm{m})$, whereas in T. pinivora $(47-492 \mu \mathrm{m})$ and in $T$. processionea $(56-351 \mu \mathrm{m})$ the same ratios were equal to 10 and 6 times, respectively. Previously published measures of the range were much lower: for T. pityocampa, 80-160 $\mu \mathrm{m}$ (Scheidter 1934), 93-415 $\mu \mathrm{m}$ (Hase 1939), and 150-250 $\mu \mathrm{m}$ (Lamy 1990); for T. pinivora: 60-260 $\mu \mathrm{m}$ (Démolin 1963); and for $T$. processionea: 150-250 $\mu \mathrm{m}$ (Lamy 1990) and 85-290 $\mu \mathrm{m}$ (Fenk et al. 2007). These differences may be ascribed to differences in setal extraction methods and sample sizes.

In $T$. pityocampa and $T$. pinivora the distribution of setal length can be considered as bimodal (Sokal \& Rohlf 1995), with a first peak in the class of 50-100 $\mu \mathrm{m}$, and a second in the class of 200-250 $\mu \mathrm{m}$. In the only other species of same genus where the distribution of setal length has been studied, the oak processionary moth $T$. processionea, the distribution appears unimodal (Fenk et al. 2007), confirming our measures obtained for the same species. Bimodality in $T$. pityocampa and $T$. pinivora can be explained by the overlapping of two normal distributions for each of the length classes. Actually the short and long setae are intermixed throughout the mirror, as demonstrated by our observations at the SEM microscope. There are few published examples of variation in setal size, such as in the adult female of Anaphe venata Butler (Notodontidae) (Lamy et al. 1984), but no interpretation about the importance of setal size is given. As in the studied species of Thaumetopoea the general shape of the seta is the same, the different size may affect both dispersion and skin penetration. In other arthropods, however, such as the brown tail moth Euproctis chrysorrhoea (Linnaeus) 
(Kemper 1955) and South American tarantula spiders (Cooke et al. 1972), the setae display a high variation of shape that could be potentially linked to a different function (Battisti et al. 2011). The absence of bimodality in T. processionea, despite a large interval of variation, remains unexplained and it is possibly related to a different evolutionary history of this species, the only one in the genus feeding on oaks (Quercus spp.) over all Europe (Groenen \& Meurisse 2012).

The role of seta size in protection from predation can be discussed in relation to what is known about the defense mechanism. Battisti et al. (2011) pointed out that the urticating setae are an efficient defense system for the colony but not for the individual, as the symptoms appear with a delay of time, when the larva has been already killed. Although these conclusions have been taken based on the reaction development in humans, it is unlikely that birds or mammalian predators would respond differently. As setae disperse as a cloud around the colony (Fenk et al. 2007), with high concentration of short setae up to $6 \mathrm{~km}$ (during the day) and $12 \mathrm{~km}$ (during the night), they could have the function to keep away predators. In this case, the larger and denser is the cloud, the stronger is the protection; in this case the diversity of seta size may extend such a barrier much farther, with a direct benefit for the colony. In this case, one could speculate that other preys of vertebrate predators could indirectly benefit of the protection, and thus competition among insect herbivores should increase. Although the mechanism needs to be elucidated with appropriate experiments, the large investment into urticating setae made by these species of processionary moths indicates that the benefits from an extended protection are higher than the costs possibly imposed by competition.

The seta size can be also important for impacts on humans and on domestic mammalians, such as pets and livestock. The penetration of setae into the skin was firstly studied by Hase (1939) on T. pityocampa, showing that the seta enters with the sharp basal end and it is helped by barbs on the distal end. Although this study explored variation in seta size, the range identified was smaller than that of our study and setal size was not considered as a possible factor affecting the penetration efficiency. We hypothesize that the variation of setal size may involve a different capacity of setae to penetrate the skin of target organisms. As Fagrell et al. (2008) developed a method to detect setae in human skin for several days after the contact, it could be interesting to explore what happens with setae of different size. The variation in seta size may also be 
related to potential differences in their allergenic content, which appears to be much more diverse than previously considered, as Rodriguez-Mahillo et al. (in press) showed that setae of $T$. pityocampa contains at least seven different allergens. Another important point is the setae dispersion in the environment and the possible consequences for humans and domestic mammalians. Most records of serious symptoms observed in people living nearby trees infested by the pine processionary moths $T$. pityocampa (Vega et al. 2011), the northern pine processionary moth T. pinivora (Holm et al. 2009), and the oak processionary moth T. processionea (Maier et al. 2003; Gottschling \& Meyer 2006) are associated with airborne material, suggesting the importance of setal size for dispersion. This assumption is relevant for the prediction of areas of risk exposure and for diagnostics, as symptoms are often reported without a specific reference to the organism that may have caused them (Hossler 2009).

In conclusion, the awareness of a great variation in size of urticating setae may open the way to a better modeling of both the ecology of the systems and the risks to which humans and domestic mammalians are exposed. In the case of processionary moth, such a risk is very high due to the wide distribution of host plants in both urban and forest areas (EFSA 2009). This is emphasized by a continuous release of setae from the soil or from tents, because of their high persistence. The information provided in this paper may offer an opportunity to explore the importance of setal size for protection from predation and for risk assessment toward non-target vertebrates and humans. In addition, it may be useful to pest managers and decision makers in planning the control operations of these forest and urban tree pests.

\section{References}

Barbaro L, Battisti A (2011). Birds as predators of pine processionary moth (Lepidoptera: Notodontidae). Biological Control 56, 107-14.

Battisti A, Holm G, Fagrell B, Larsson S (2011). Urticating hairs in arthropods - their nature and medical significance. Annual Review of Entomology 56, 203-220.

Cooke JAL, Roth VD, Miller FH (1972). The urticating hairs of theraphosid spiders. American Museum Novitates 2498, 1-43.

Cox RG (1970). The motion of long slender bodies in a viscous fluid 1: General theory. Journal of Fluid Mechanics 44, 791-810. 
Démolin G (1963). Les 'miroirs' urticants de la processionnaire du pin (Thaumetopoea pityocampa Schiff.). Revue de Zoologie Agricole et Appliquée 10-12, 107-14.

EFSA (2009). Scientific Opinion of the Panel on Plant Heath on a pest risk analysis on Thaumetopoea processionea L., the oak processionary moth, prepared by the UK and extension of its scope to the EU territory. The EFSA Journal 1195, 1-64.

Fabre JH (1900). Souvenirs entomologiques, études sur l'instinct et les moeurs des insectes. Delagrave, Paris.

Fagrell B, Jörneskog G, Salomonsson AC, Larsson S, Holm G (2008). Skin reactions induced by experimental exposure to setae from larvae of the northern pine processionary moth (Thaumetopoea pinivora). Contact Dermatitis 59, 290-95.

Fenk L, Vogel B, Horvath H (2007). Dispersion of the bio-aerosol produced by the oak processionary moth. Aerobiologia 23, 79-87.

Fuentes Aparicio V, Zapatero Remón L, Martínez Molero MI et al. (2006). Allergy to pine processionary caterpillar (Thaumetopoea pityocampa) in children.

Allergologia et Immunopathologia 34, 59-63.

Gilmer PM (1925). A comparative study of the poison apparatus of certain lepidopterous larvae. Annals of the Entomological Society of America 18, 20339.

Gottschling S, Meyer S (2006). An epidemic airborne disease caused by the oak processionary caterpillar. Pediatric Dermatology 23, 64-66.

Groenen F, Meurisse N (2012). Historical distribution of the oak processionary moth Thaumetopoea processionea in Europe suggests recolonization instead of expansion. Agricultural and Forest Entomology 14, 147-55.

Hase A (1939). Über den Pinienprozessionsspinner und über die Gefährlichkeit seiner Raupenhaare (Thaumetopoea pityocampa Schiff.). Anzeiger für Schädlingskunde 15, 133-42.

Hossler EW (2009). Caterpillars and moths. Dermatology and Therapy 22, 353-66.

Holm G, Sjoberg J, Ekstrand C et al. (2009). Tallprocessionsspinnare - stort hälsoproblem på södra Gotland. Lakartidningen 106, 1891-94.

Kawamoto F, Kumada N (1984). Biology and venoms of Lepidoptera. In: Handbook of Natural Toxins. Vol. 2. In: Tu AT eds, Insect Poisons, Allergens, and other Invertebrate Venoms. Dekker, New York, pp. 291-330. 
Kemper H (1955). Experimentelle Untersuchungen über die durch Afterwolle von Euproctis chrysorrhoea (Lepidoptera) erzeugte Dermatitis, vergleichen mit der Wirkung von Arthropodenstichen. Zeitschrift für Angewandte Zoologie 55, 3759.

Lamy M, Ducombs G, Pastureaud MH, Vincendeau P (1982). Productions tégumentaires de la processionnaire du pin (Thaumetopoea pityocampa Schiff.) (Lépidoptères). Appareil urticant et appareil de ponte. Bulletin de la Société Entomologique de France 107, 515-29.

Lamy, M, Pastureaud MH, F Novak F, Ducombs G (1984). Papillons urticants d'Afrique et d'Amérique du sud (g. Anaphe et g. Hylesia): Contribution du microscope électronique à balayage à l'étude de leur appareil urticant et à leur mode de action. Bulletin de la Société Zoologique de France 109, 163-77.

Lamy M (1990). Contact dermatitis (erucism) produced by processionary caterpillars (genus Thaumetopoea). Journal of Applied Entomology 110, 425-37.

Maier H, Spiegel W, Kinaciyan T, et al. (2003). The oak processionary caterpillar as the cause of an epidemic airborne disease: survey and analysis. British Journal of Dermatology 149, 990-97.

Matthioli PA (1568). I discorsi di M. Pietro Andrea Matthioli, medico cesareo nelli sei libri di Pedacio Dioscoride Anazarbeo. Valgrisi, Venezia.

Moneo I, Vega JM, Caballero ML, Vega J, Alday E (2003). Isolation and characterization of Tha $\mathrm{p} 1$, a major allergen from the pine processionary caterpillar Thaumetopoea pityocampa. Allergy 58, 34-37.

Mullen GR (2009). Moths and butterflies (Lepidoptera). In GR Mullen, LA Durden eds. Medical and Veterinary Entomology, Elsevier, Amsterdam, pp. 353-70.

Novak F, Pelissou V, Lamy M (1987). Comparative morphological, anatomical and biochemical studies of the urticating apparatus and urticating hairs of some Lepidoptera: Thaumetopoea pityocampa Schiff., Th. processionea L. (Lepidoptera, Thaumetopoeidae) and Hylesia metabus Cramer (Lepidoptera, Saturniidae). Comparative Biochemistry and Physiology 88, 141-46.

Pesce H, Delgado QA (1971). Poisoning from adult moths and caterpillars. In Bürchel W, Buckley EE eds. Venomous Animals and Their Venoms, Vol. III: Venomous Invertebrates Academic, New York, pp. 119-56. 
Rodriguez-Mahillo AI, Gonzalez-Muñoz M, Vega JM et al. in press. Setae from the pine processionary moth (Thaumetopoea pityocampa) contain several relevant allergens. Contact Dermatitis.

Santos-Magadán S, González de Olano D, Bartolomé-Zavala B, Trujillo-Trujillo M, Meléndez-Baltanás A, González-Mancebo E (2009). Adverse reactions to the processionary caterpillar: irritant or allergic mechanism? Contact Dermatitis 60, 109-10.

Scheidter F (1934). Auftreten der "Gifthaare" bei den Prozession-spinnerraupen in den einzelnen Stadien. Zeitschrift fur Pflanzenkrankheiten und Pflanzenschutz 44, 223-26.

Sokal RR, Rohlf FJ (1995). Biometry: the principles and practice of statistics in biological research. 3rd ed. Freeman, New York.

Specht A, Corseuil E, Barreto Abella H (2008). Lepidopteros de importancia medica. Principais especies no Rio Grande do Sul. USEB, Pelotas, Brasil.

Vega JM, Moneo I, Armentia A, Fernandéz A, et al. (1999). Allergy to processionary caterpillar (Thaumetopoea pityocampa). Clinical \& Experimental Allergy 29, 1418-23.

Vega JM, Moneo I, García Ortiz JC, Sánchez Palla P, et al. (2011). Prevalence of cutaneous reactions to pine processionary moth (Thaumetopoea pityocampa) in an adult population. Contact Dermatitis 64, 220-28.

Werno J, Lamy M (1990). Animal atmospheric pollution: the urticating hairs of the pine processionary caterpillar (Thaumetopoea pityocampa Schiff.) (Insecta, Lepidoptera). Comptes Rendus de l'Académie des Sciences, Paris, Série III 310, 325-31. 
Figure 1. Distribution of the aerodynamic diameter of the setae in the three species of Thaumetopoea.

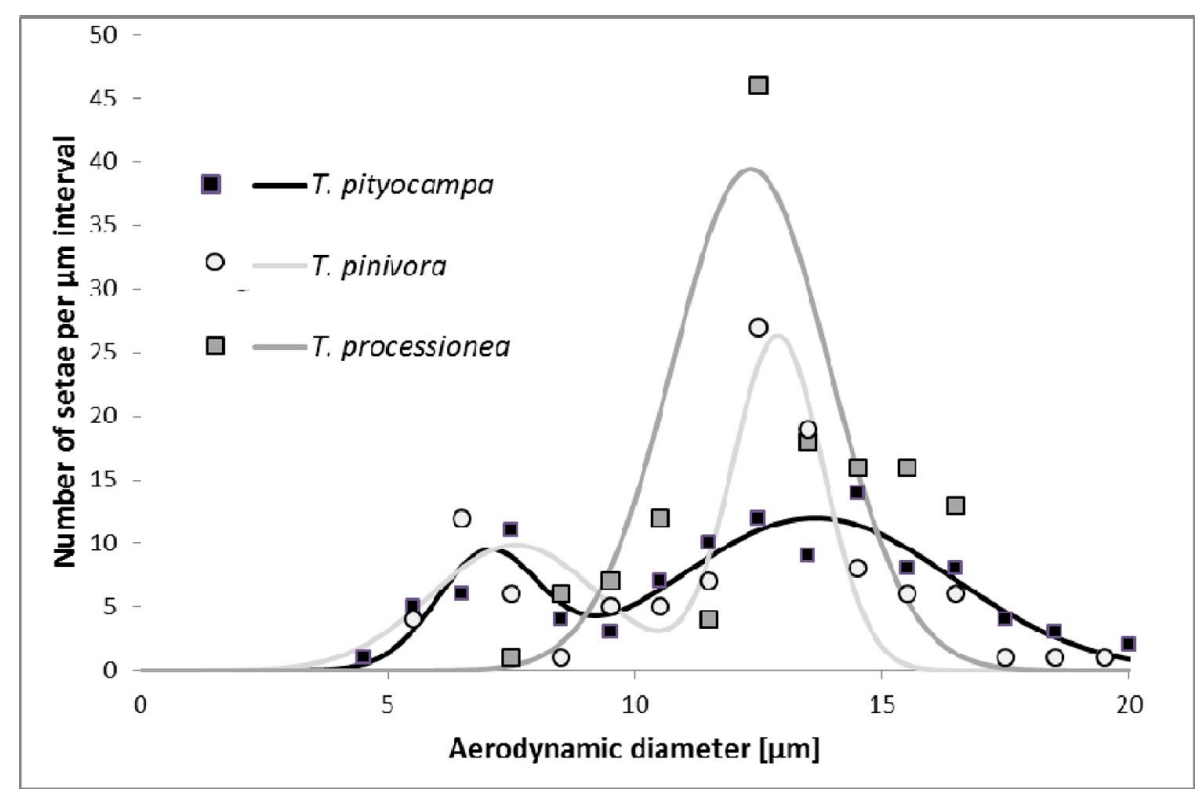


Figure 2. Relationships between length and diameter of setae in the three species of Thaumetopoea.

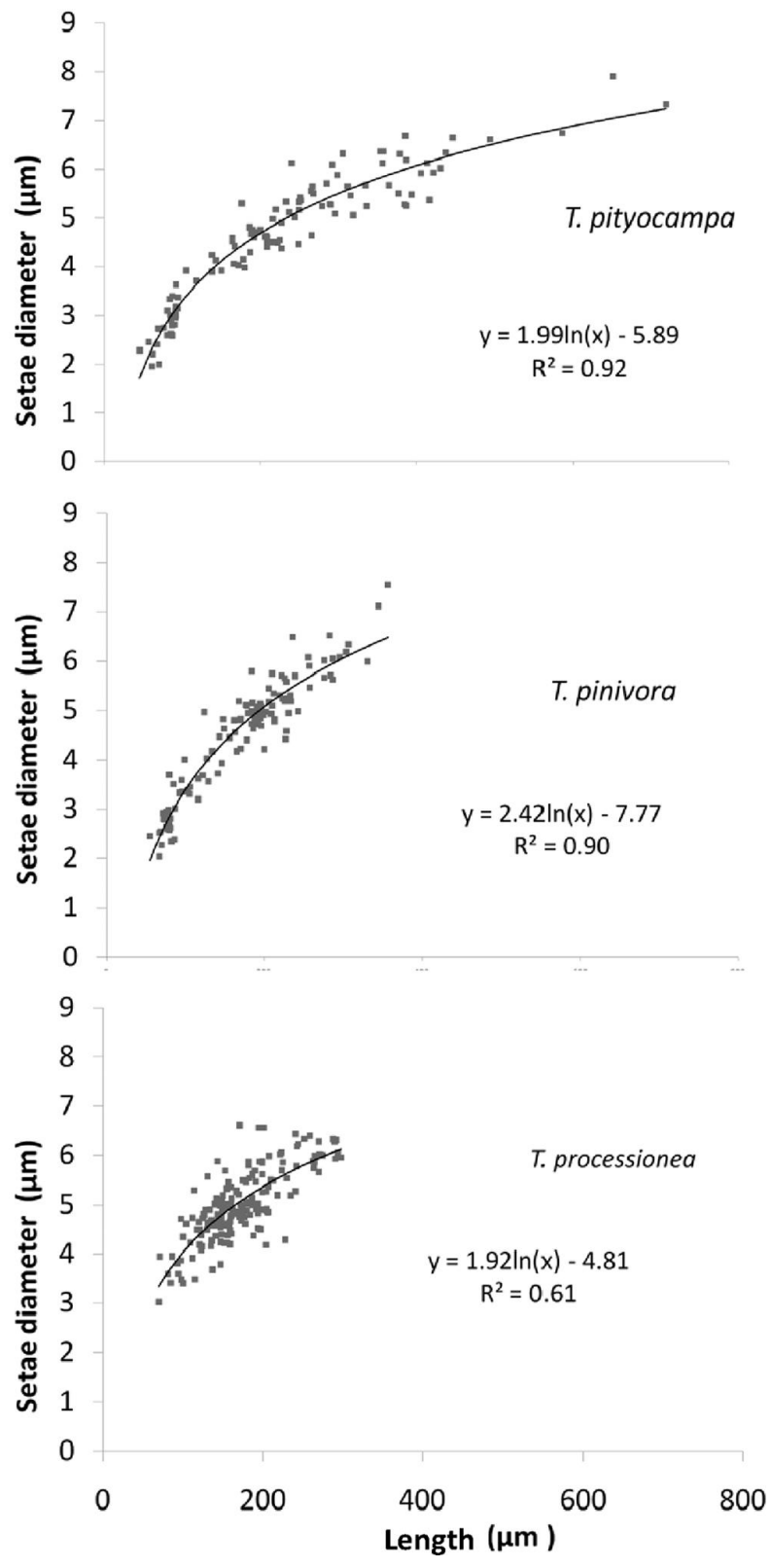


Figure 3. Length of setae released by the three species of Thaumetopoea in a laboratory test.

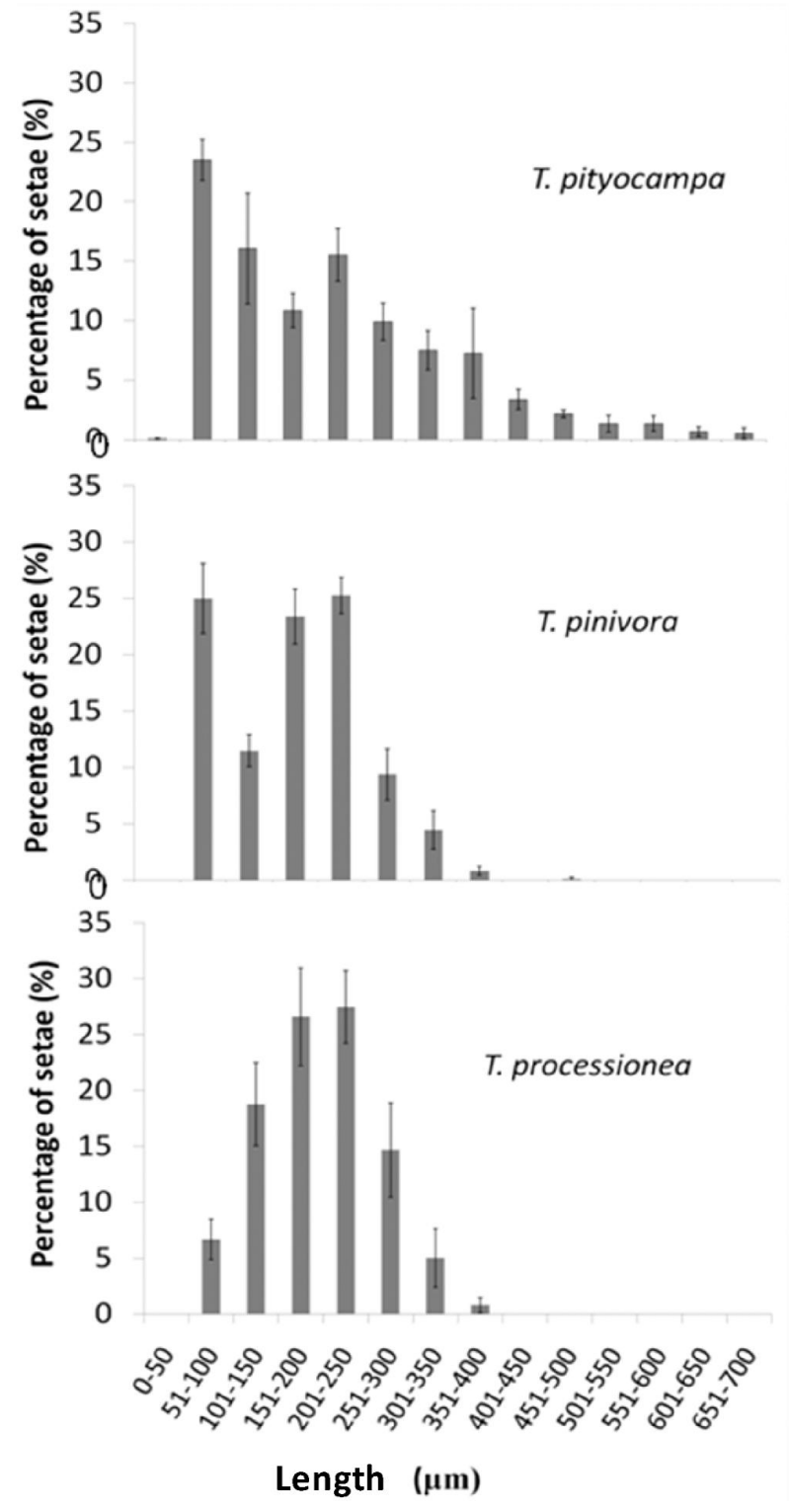


Figure 4. SEM images of the urticating apparatus in three Thaumetopoea species (from the left, T. pityocampa, T. pinivora, $T$. processionea) showing the occurrence of short and long setae intermixed in T. pityocampa and T. pinivora.
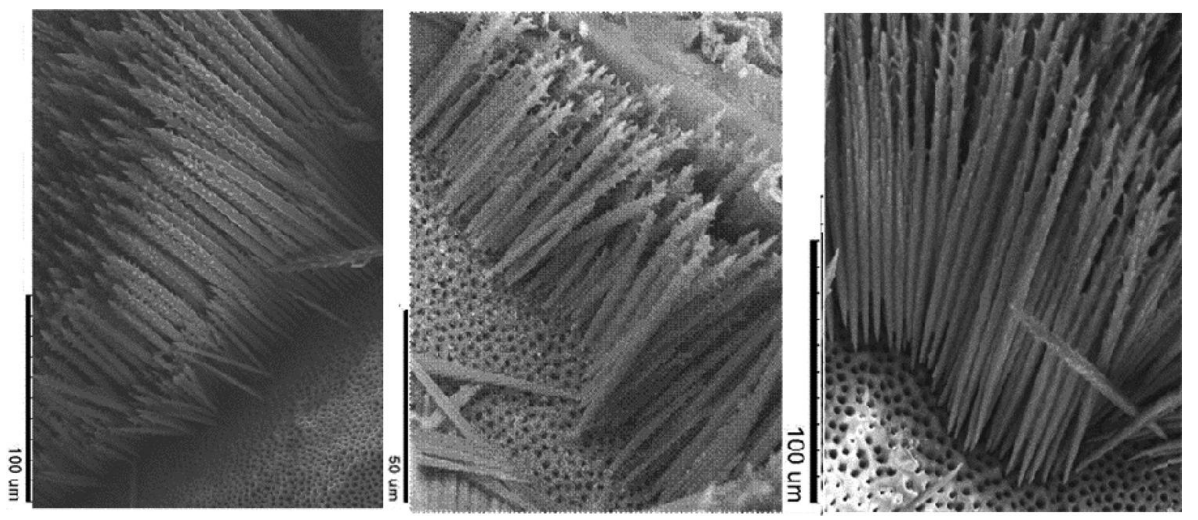